Citation: SYLVESTER, Á. (2021)

Meeting the Loffice: Community office building, Budapest, Hungary

Metszet, Vol 12, No 1, pp 40-45.

https://doi.org/10.33268/Met.2021.1.5

Received: 25 January 2021

Accepted: 2 February 2021

Published: 4 March 2021

Abstract: Walking around the main boulevard in Budapest this building jumps out from a backstreet, the bold use of white finishes and a four-floor high themed, figurative, monumental shading device raise this project above its surroundings. Instantly leading any passerby to consider what is the function and who are the users? A fresh approach to community office space, somewhere on the borderline between loft living and office aesthetic. A building which at first glance seems to be luxurious regarding its function on closer inspection reveals its inner humble character, inspiring creativity and positivity.

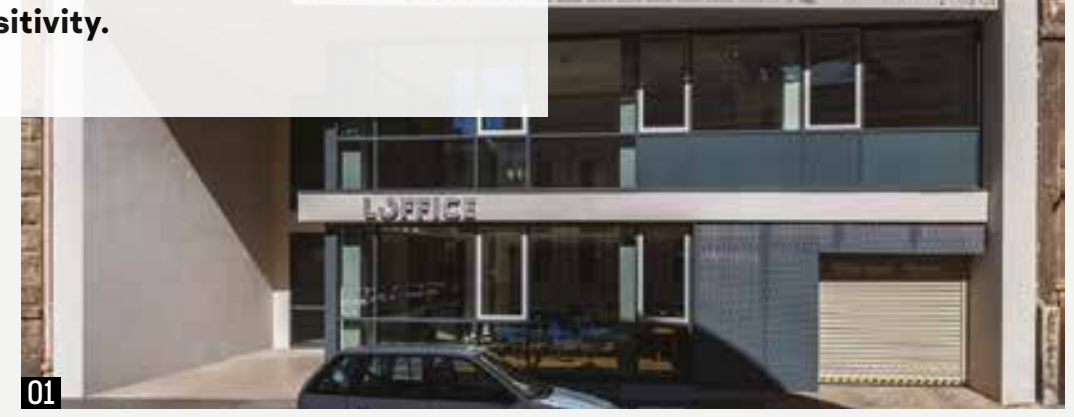
01 Monokróm, csipke finomságú homlokzat Utcakép a Kissalétrom utca felől

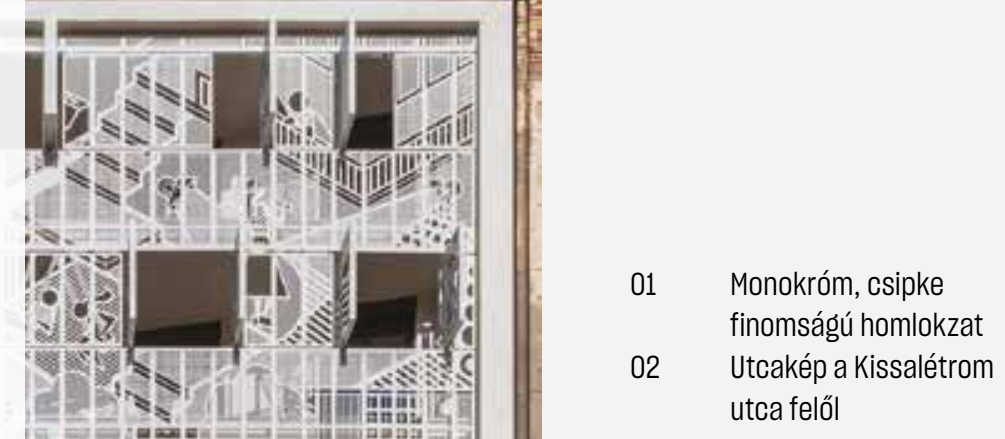

\title{
TALÁLKOZÁS \\ A SALÉTROM UTCAI LOFFICE ÉPÜLETTEL
}

\section{KÖZÖSSÉGI IRODAHÁZ | BUDAPEST}

\section{ELSŐ LÁTOGATÁS}

_ Tavaly szeptember 3-án délelőtt feleségemmel szokásos sétáink egyikén a József körút bal oldalán a Duna felé haladva, a Kissalétrom utcán betekintve pillantottam meg a házat. Azonnal megragadott a látvány. Elsőre a homlokzat bal oldali tűzfalcsatlakozásánál, a második szint fölött négy, egymás felett megjelenő, négyzetbe szerkesztett homlokzati elem belső osztásrendje fogott meg. „Tanult ember rajzolhatta.” A mellette lévő és ugyancsak négyzetbe szerkesztett, négy szint magas, fehér színü, tematikus, figuratív, monumentális, áttört árnyékoló felületet megnyerőnek találtam de sugárzó ereje ellenére építészeti indokoltságát pár pillanatig keresnem kellett. Eszembe ötlött Diego Rivera [I] mexikói monumentális homlokzati falfestészete, illetve a Budapesten is terjedő tűzfalfestészet mint előzmény, de az újdonság, hogy - általam eddig még nem látott módon - az épület arcát takarja, késleltette a felismerést. Menyasszonyi fátyol? Hirdetőfelület? Minden szakralitást nélkülöző, üdén profán jelenség, monokróm, csipke finomságú. Tagoltságának köszönhetően az épület nem takart homlokzati felületeivel harmonikus egységben él. Zseniális.

_ Közeledve fedeztem fel a ferdén hátrahúzott két szint magas üveghomlokzat első emeleti födémmagasságában, fehér sávban megjelenő feliratot: LOFFICE. A loft és office szópár összevonása valószínűleg az épület használatát hirdeti. A loft szó az amerikai félipari-ipari városi negyedekben előforduló elhagyott, de lakás- és vagy irodai célokra újrahasznosított építészeti terek friss miliőjét ígéri. 



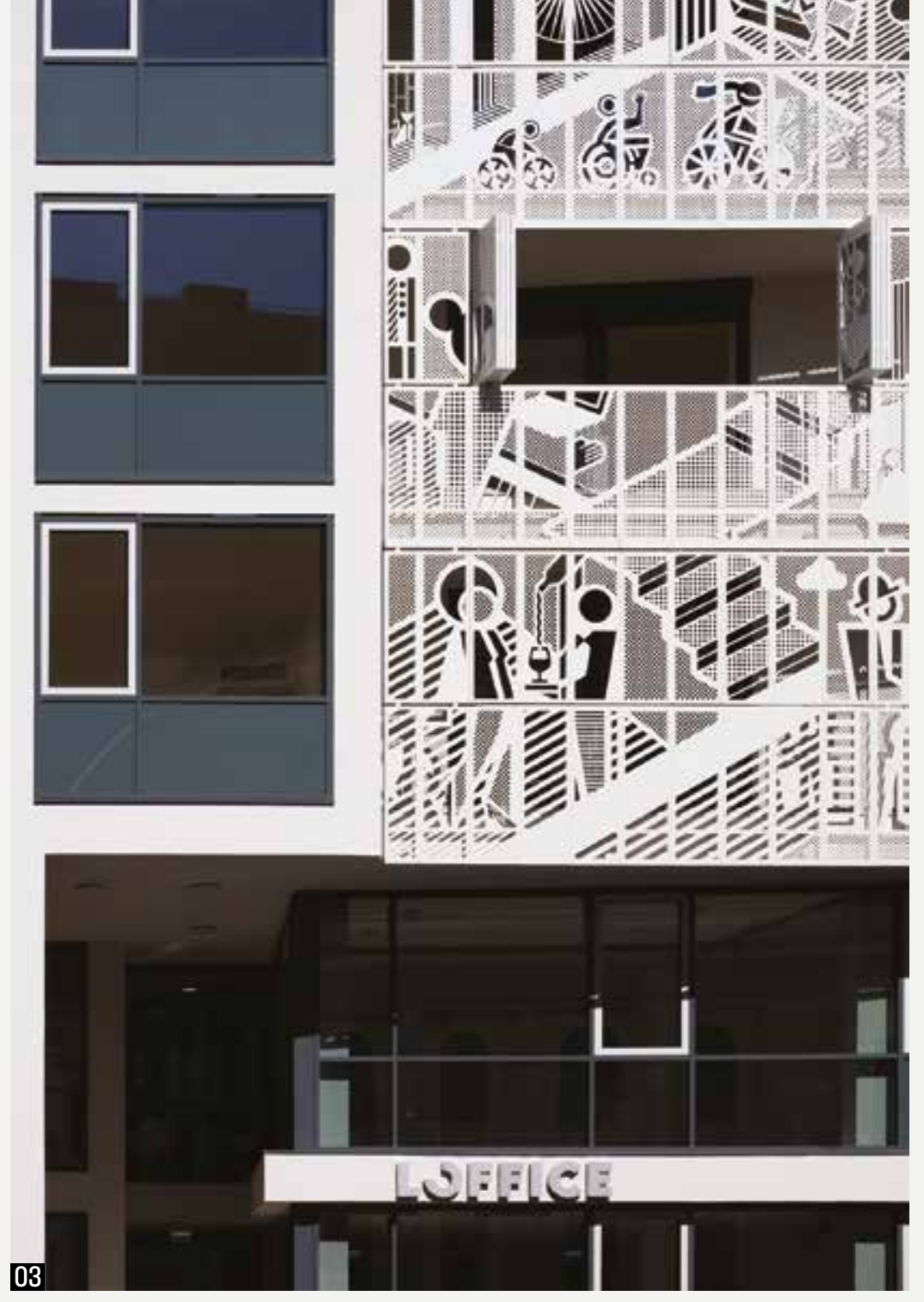

03

húzódnak

04 A kezelóerkélyekre vetődő árnyékok

05 Az árnyékoló csomópontja

A nyitható árnyékoló mögött kezelőerkélyek
Izgalmas álperspektivikus hatást kelt. Innen fentről a telek határa felé induló egykarú lépcsőn át lehet a tetőteraszra feljutni. Itt fedeztük fel, hogy az alápincézett épület fszt. + 6 emelet magas: a legfelső emelet az utcai homlokzat mögé jelentősen hátrahúzott penthouse, mély tetőterasszal. Ennyit láttunk és tudtunk meg a lelkesítő látogatás alkalmával, ahol a minket kedvesen fogadó csinos hölgyalkalmazottak büszkén tájékoztattak az épület céljáról, használatáról. Idézet az alapító tulajdonosoktól: „Ma a Loffice 2 országban, 3 helyszínen nyújt rugalmas feltételekkel használható infrastruktúrát, és egy olyan támogató légkört, amely napról napra lehetőséget nyújt a szakmai és emberi kapcsolatok építésére, ihletszerzésre és önfejlesztésre. Az ötlet 2005-ben indult az Egyesült Államokból. Egy olyan költséghatékony irodamegoldást biztosít szabadúszók és neonomádok számára, ahol a rendelkezésre álló infrastruktúra másokkal megosztva használható. Ma a helyfüggetlen munkavégzés már nem csak a vállalkozók körében kedvelt, és az egyéb megosztáson alapuló szolgáltatások is mindennapjaink szerves részévé váltak.” [2] _ Valóban loft office született, szerényen háttérben maradó, sokféle használatot kínáló, befogadó építészeti hangvétellel.

Ami páratlan, hogy kérdésemre; tudják-e, hogy ki az épület építésze, nemcsak a nevét, hanem a közeli irodája címét is megadták. El is zarándokoltunk az irodába, de nem találkoztunk. Dicsérő üzenetet hagytam...

\section{MÁSODIK LÁTOGATÁS}

_ A neten történő találkozások után személyesen először ez év január I2-én találkoztunk a helyszínen.

_ Az időközben a kézhez kapott tervek birtokában kérésemre először is a pincei gépkocsitárolót kerestük fel. Aki épület alatti mélygarázst valaha már tervezett, tudja, hogy a használható és geometriai veszteségek nélküli parkoló milyen mértékben teremt kényszerű szerkesztési körülményeket a felette lévő épület alaprajzi kialakítására, különösen tartószerkezeteinek pozíciójára. A tervekből tudtam meg, hogy a teljes telek alápincézett. A terv helyesen autólift használatát írta elő a jobb oldali tűzfal mellé, a bejárattal átellenes oldalra telepítve. Így 4 parkolósáv és 2 tágasabb közlekedősáv jött létre a lift szélességében hátrafutó közlekedővel feltárva. Kerestem és megtaláltam a kétszintes egyterű irodaszárny szerkezeteit meghatározó, ferdén futó tengely indokoltságát és az ebből következő pillérrendszer összes elemének pozícióját: a ferde vonalnak a pincében a leghátsó parkolósáv harmadában lévő pillértengelyen kell átlósan átfutnia, valamint a földszinti bejárat lift-lépcsőház torony engedte megfelelő szélességet megteremtő támasz tengelyén. Továbbiakban: a többszintes épület homloksíkját a jobb oldali tűzfalra merőlegesen volt érdemes számtalan építészeti előny érdekében felvenni. A legjelentősebb előny a hőszigetelt utcai homlokzat és a csipkeszerü, gigantikus nyugati árnyékoló között végigfutó kezelőerkélyek létrehozása. Általában elmondható, hogy a telek szabálytalan geometriájából is adódóan 


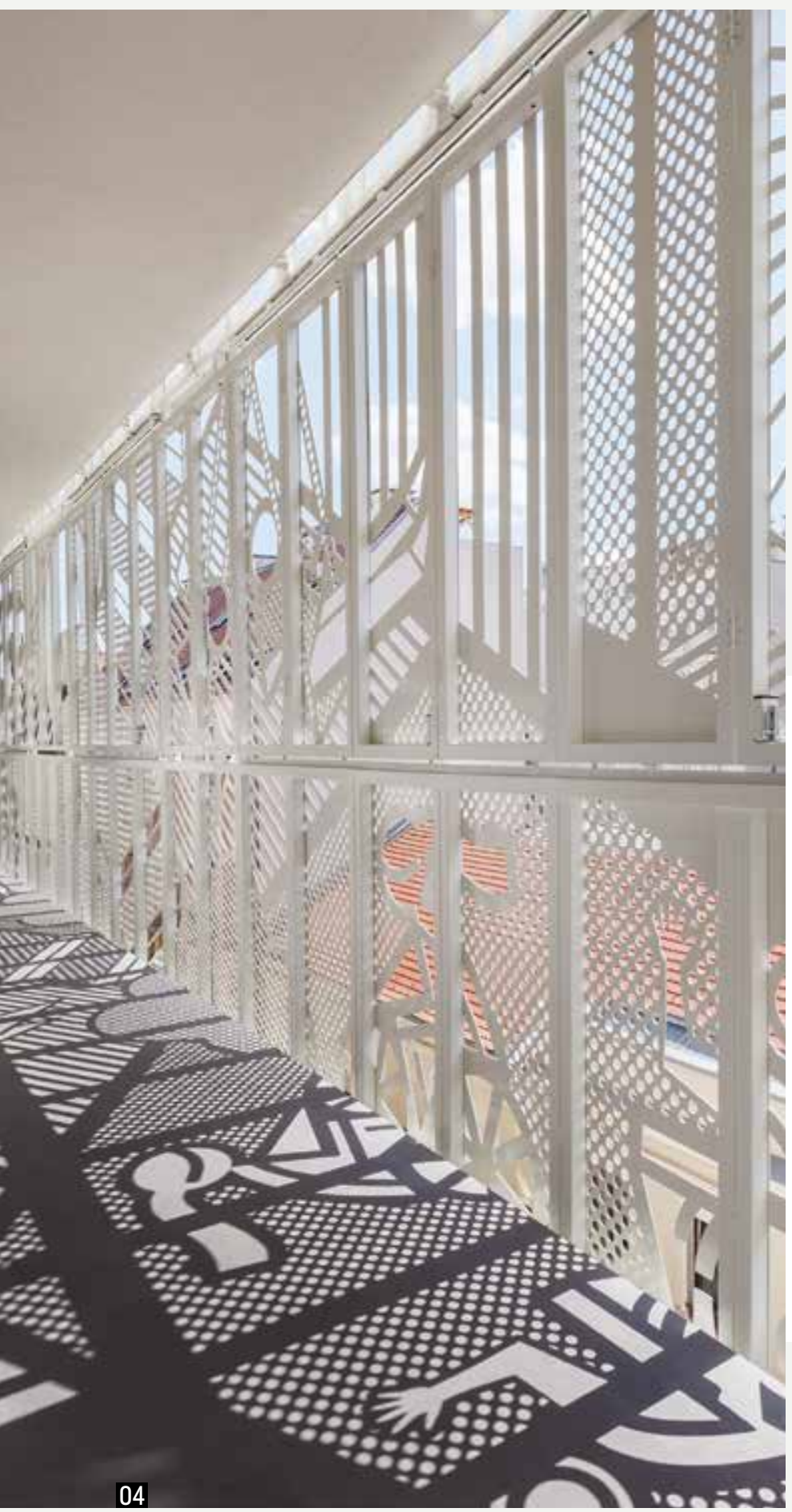

a derékszögtől finoman eltérő alaprajzi pozíciók sejtelmessége szinte alig érezhető kellemes érzeteket kelt.

_ Az épület felsőbb szintjein középfolyosós elrendezésben vegyesen lakások és irodaterek időről időre változtathatóan alakíthatóak ki. Teakonyhák, toalettek és fürdőszobák épültek ki a középfolyosó mentén kialakított függőleges felszálló pontokra szervezve. A déli tűzfal melletti két, kádas, bidés fürdőszoba talán luxusnak tünik. A hidegpadlók, falburkolatok antracitszürke Zalakerámia greslapokkal készültek, a szaniterek hófehérek, a melegpadlók ipari parketták, festett törtfehér festések gipszkarton válaszfalakon, illetve vakolt téglafalakon. A penthouse felületeinek hangvétele az alatta lévő szintekéivel azonos. A nagyméretű terasz burkolata is szürke greslapokkal történt. Mellvédje az alatta lévő szintek udvari erkélyeihez hasonlóan befogott üvegezéssel készült. Árnyékolása messze kinyúló, motorosan működtetett szerkezettel

\begin{tabular}{|c|c|c|c|}
\hline A & Horganyzott acél konzol & $\mathbf{G}$ & Schüco FW 50+.HI \\
\hline B & $\begin{array}{l}\text { Szinterezett alumínium } \\
\text { perforált korlátelem }\end{array}$ & & $\begin{array}{l}\text { alumínium függönyfal, } \\
\text { háromrétegü }\end{array}$ \\
\hline \multirow[t]{3}{*}{ C } & Szinterezett nyitható & $\mathbf{H}$ & Purenit hőszigetelés \\
\hline & alumínium perforált & I & Háromrétegú \\
\hline & árnyékoló elem & & üvegezéssel ellátott \\
\hline \multirow[t]{4}{*}{ D } & Szinterezett nyitható & & ALU/müanyag nyílászáró \\
\hline & alumínium perforált & & a hőszigetelés síkjába \\
\hline & árnyékoló alsó & & beépítve \\
\hline & megfogása & J & $30 \times 23 \mathrm{~cm}$-es \\
\hline \multirow[t]{4}{*}{ E } & Szinterezett nyitható & & előregyártott hőszigetelő \\
\hline & alumínium perforált & & redőnytok \\
\hline & árnyékoló függesztett & K & Függönykarnis \\
\hline & görgős kialakítása & $\mathbf{L}$ & Szinterezett nyitható \\
\hline $\mathbf{F}$ & $\begin{array}{l}40 / 40 / 4 \text { horganyzott acél } \\
\text { keretszerkezet }\end{array}$ & & $\begin{array}{l}\text { alumínium perforált } \\
\text { árnyékoló rögzítése }\end{array}$ \\
\hline
\end{tabular}
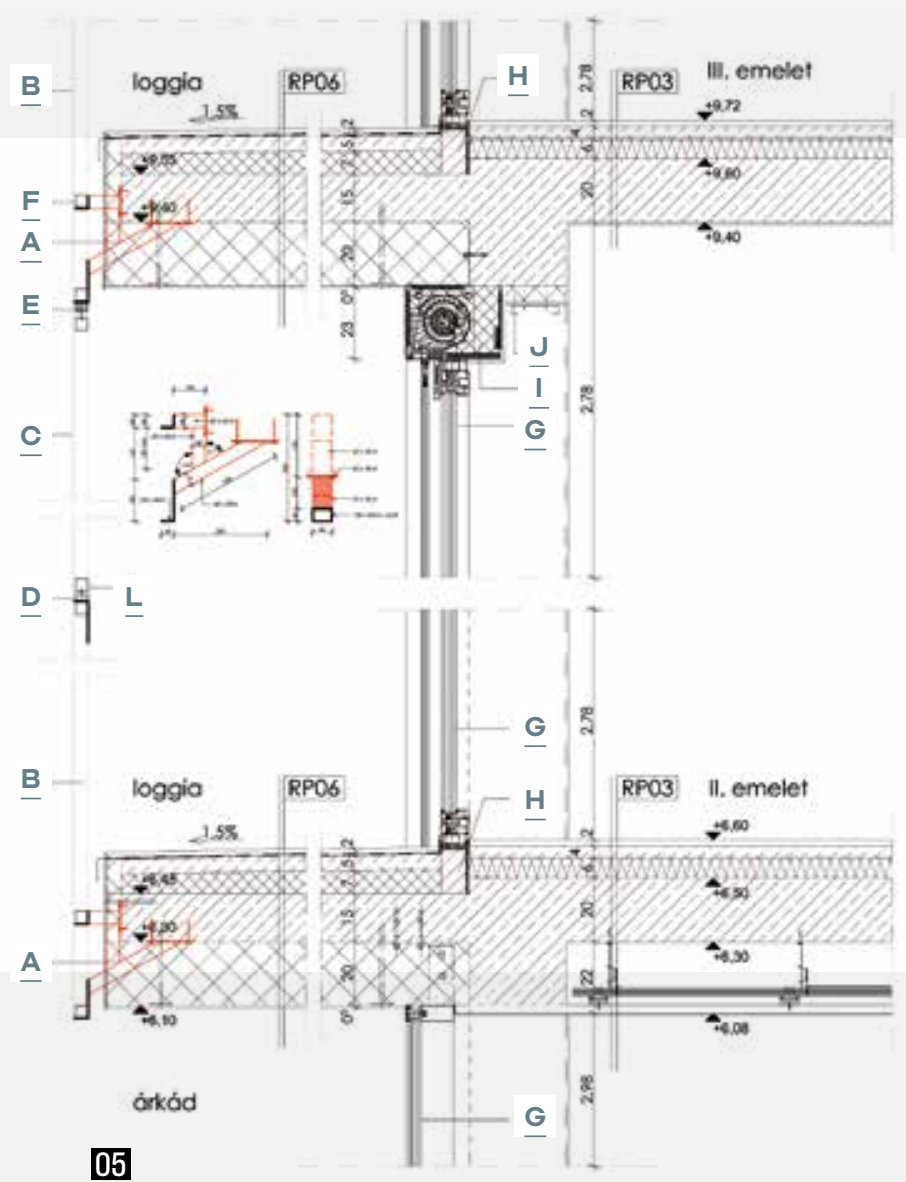

történik. Általában meg kell jegyezni, hogy az összes felületi anyag minősége, szürke és fehér színe, használata konzekvens, visszafogott és elegáns.

\section{AZ ÁRNYÉKOLÓRÓL}

_ A Salétrom utcában szemben álló egyházi épület a loffice két legalsó szintjét a legkellemetlenebb nyári délutáni, naplementei órákban megfelelően árnyékolja. Felette csakis függőleges árnyékolás jöhet szóba. Hogy a belső terek és a környezet kapcsolata fennmaradjon, csak vala- 03 milyen áttört, évszakokra és időjárásra reagáló felület létrehozása lehetett a cél. A felület I2 vízszintes és 24 függőleges tengely által tagolt, az emeleti parapetmagasságok vízszintes tengelye felett nyitható, táblás elemekkel. A vázhoz félfordítókkal rögzített táblák nyitása egyszerű pántolással, harmonikaszerűen kifordítva történik. A szerkezet 

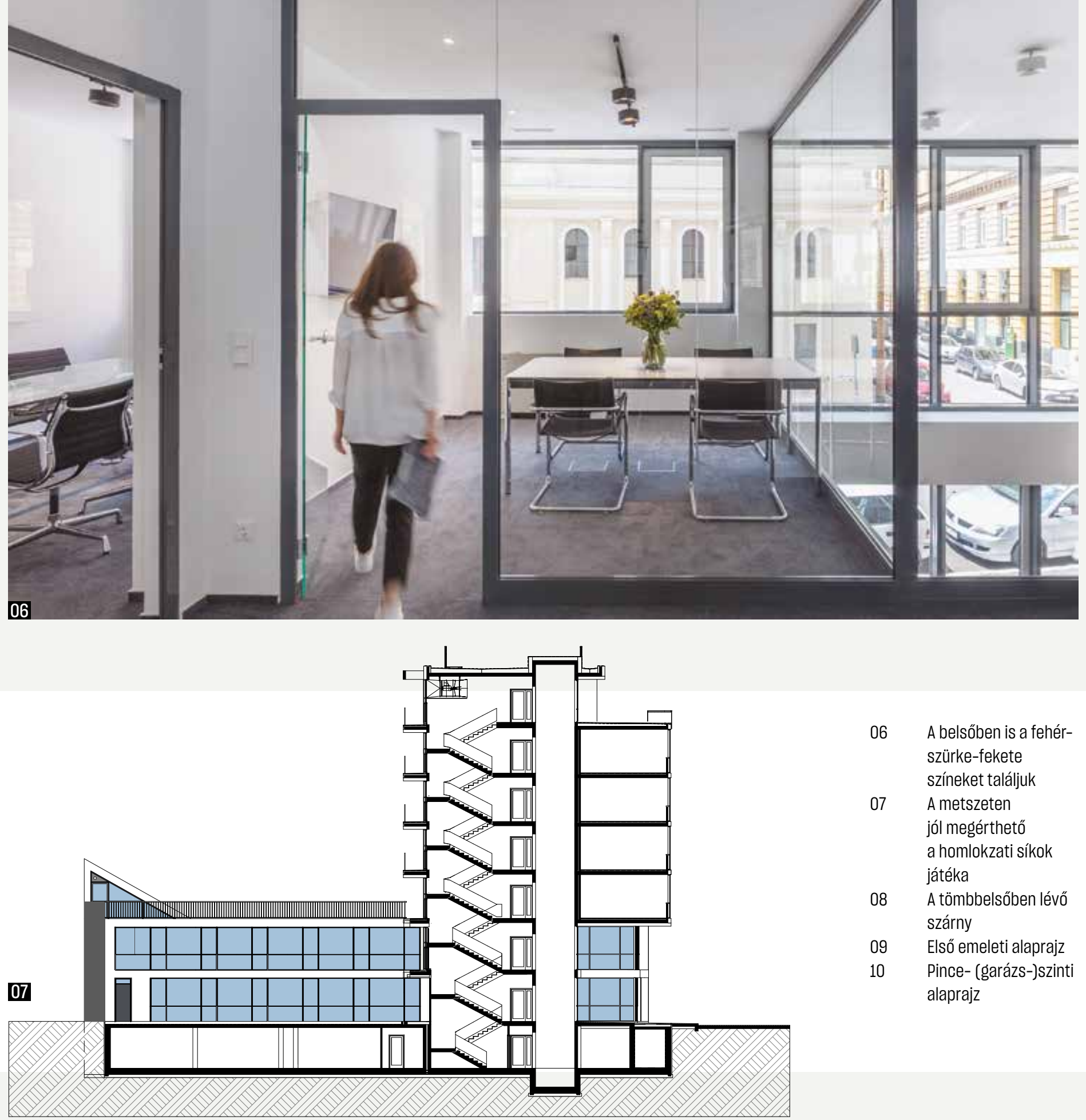

a hatékony árnyékolás mellett a belső tereknek padlóra vetülő attraktív árnyékképeket ajándékoz. A nyugati árnyé- 04 koló története a szerző leveléből idézve ismerhető meg: „A homlokzat árnyékolójának változását illetően először eltolható trapézelemekben gondolkodtam (ami az alaprajzból jött) szabályos lyukosztással vagy terpesztett lemezzel, de a grafika megszületése után a trapézforma gyengítette 05 volna a grafikát, ezért áttértem egy szigorúbb, de kevésbé előtérben lévő, derékszögű rendszere, mely innentől nyitható lett...,

—A homlokzati képeket, melyek az alapítók krédóját hirdetik, Willem Van de Ven holland grafikus készítette Esterházy Marcell képzőművésszel. Az eljárás lézervágással valósult meg.

— Nem lehet nem említeni az északi szomszéd telken álló, történetileg a loffice telkével együttműködő és engedélyezetten a loffice funkció kiterjesztését befogadó épület felújítását. Az L alakú, kétszintes, félnyeregtetős, vakolatlan téglafalas, poroszsüveg födémes épület statikai megerősitésével is járó, múemlék értékủ felújítás varázslatosan friss miliőt teremt.

_A ház egyszeri és megismételhetetlen voltával kortanúként értékes, és kiérdemelte a figyelmesen törődő bánásmódot. Telitalálat.

_ A kolumbiai Nobel-díjas író, Gabriel García Márquez titka, hogy szöveganyagai olvasata szikáran hétköznapi, mégis csodát képes teremteni. [3] Ez jutott eszembe PaládiKovács Ádám művével találkozva. 


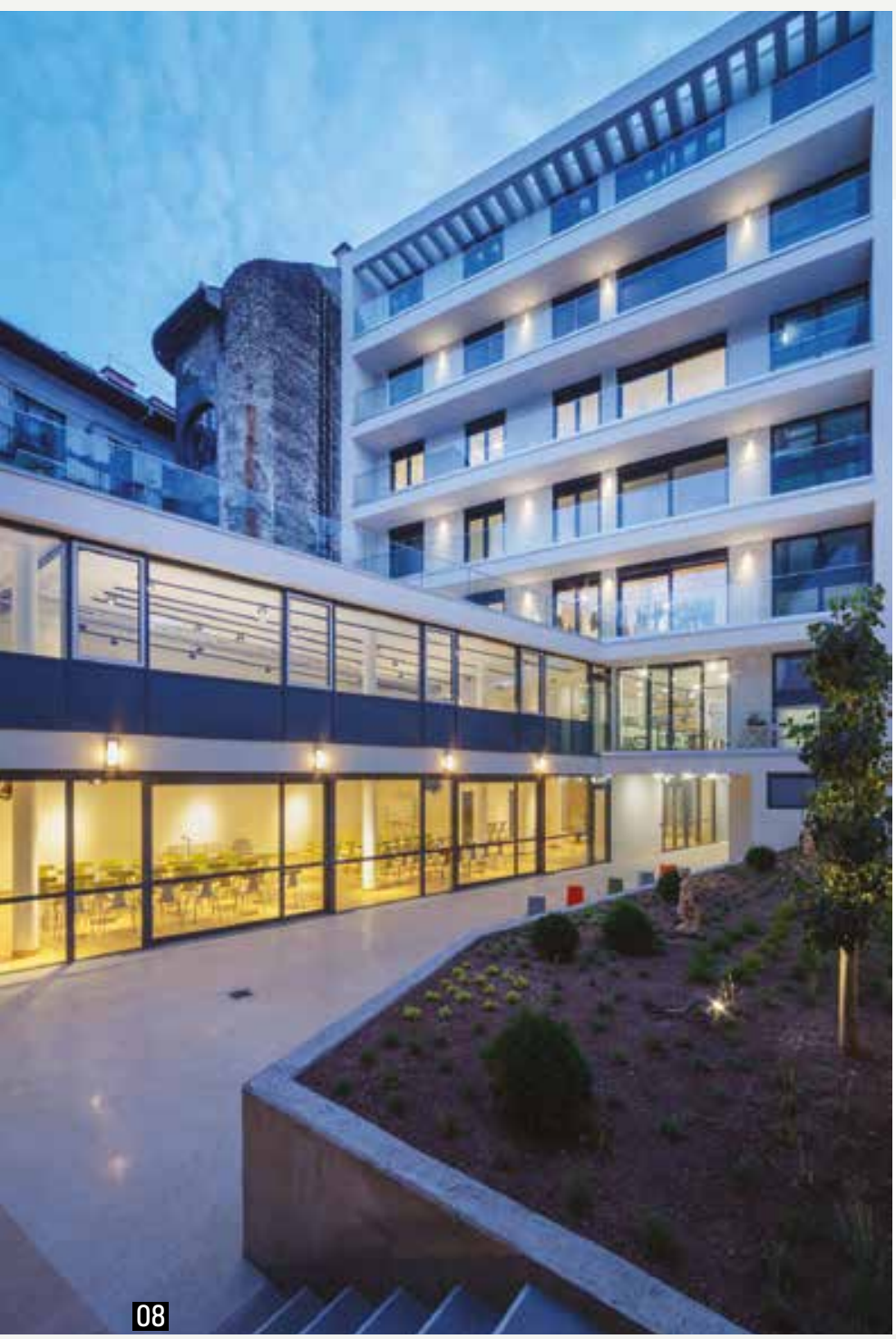

\begin{tabular}{l|ll|l} 
A & Iroda & D & Teakonyha \\
B & Tárgyaló & E & Belső udvar \\
C & Recepció & &
\end{tabular}

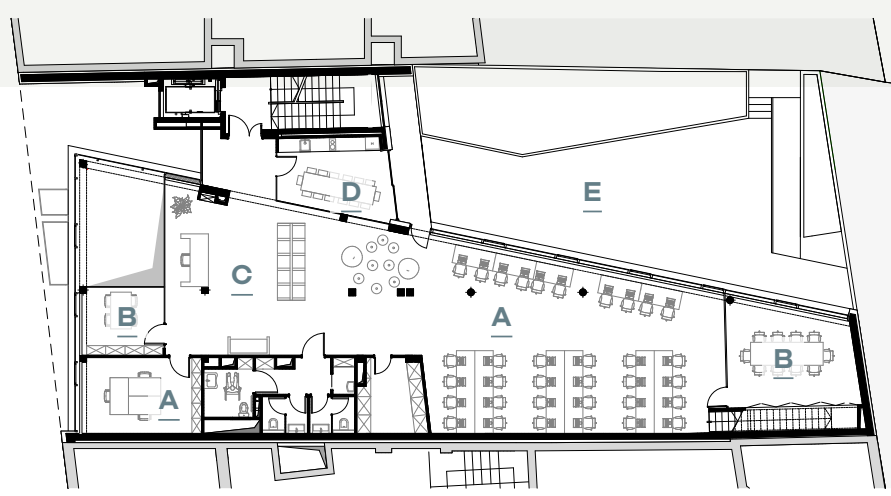

\begin{tabular}{l|ll|l} 
A & Autólift & C & Szellőzőgépház \\
B & Parkoló & D & Gépészetihelyiség
\end{tabular}

10

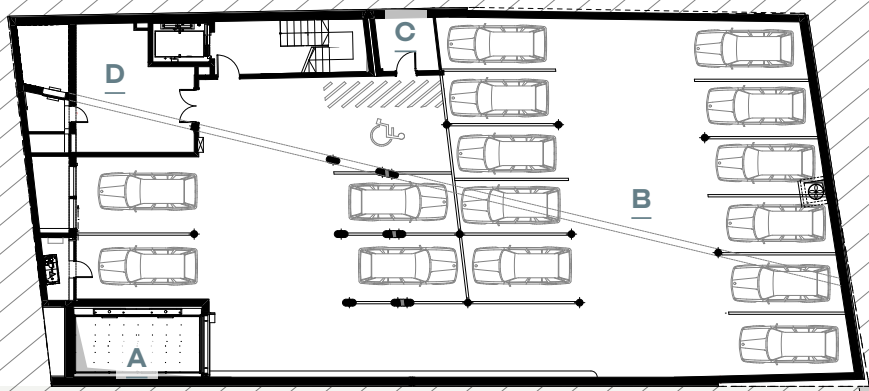

IRODALOM / REFERENCES

[1] Bayón, Damian: El Artista latinoamericano y su identidad, Monte Avila Editores, Caracas 1977, pp 1-150.

[2] Loffice/,,A misszió” [honlap], hozzáférhető: <https://loffice.hu/budapest/hu/rolunk/> [utolsó belépés: 2021-02-02].

[3] Zsolt, Angéla: Gabriel Garcia Marquez [Blasquez, Adélaîde és Durán, Armando interjú fordítása és bevezetés], hozzáférhető: <http://www.literatura.hu/ irok/xxszazad/amidrama/marquez.htm> [utolsó belépés: 2021-02-02].

ÉPÍTÉSZ MUNKATÁRSAK: Hegedűs Dávid, Szekeres Attila, Erdélyi Anett | GRAFIKA ÉS A BELSŐ JELRENDSZER TERVEZÉSE: Willem Van de Ven grafikusművész, Esterházy Marcell képzőművész | AKADÁLYMENTESÍTÉS: Szabó Henrietta | STATIKA: dr. Kovácsházy Péter | GÉPÉSZ TERVEZŐ: Szalóky László, Benkő Zoltán, Németh Tamás | KONYHATECHNOLÓGIA: Gauland András | ELEKTROMOS TERVEZŐ: Messerer László | TŰZVÉDELMI TERVEZŐ: Szaladják László | ÉPÍTTETŐ: Ulrike Rein, Klementz Kata, Oppenheim Klára, Esterházy Anna | GENERÁLKIVITELEZŐ: Szkladányi György, Somosi Viktor 